\title{
MOROVÉ SPISY PŘIPISOVANÉ MISTRU KŘIŠŤANOVI Z PRACHATIC*
}

\author{
DANA STEHLÍKOVÁ
}

\section{PLAGUE WRITINGS ATTRIBUTED TO MASTER CHRISTIAN OF PRACHATICE}

This article compares all of the hitherto identified plague writings (in Latin, Czech, and German) traditionally attributed to Christian of Prachatice (Křšst'an z Prachatic, † 1439). It contains an updated list of known copies of the individual texts and some new findings pertaining to the authorship, dating, and mutual relations between versions in the three languages. The appendix brings three different plague writings in Latin, which have been in various manuscripts identified as having been authored by Christian of Prachatice.

Keywords: plague - medieval plague writings - Christian of Prachatice (Křišt’an z Prachatic) - medieval manuscripts

DOI: $10.14712 / 23365730.2018 .9$

Křišt’an z Prachatic († 1439), dlouholetý příslušník a často také zástupce pražské artistické fakulty či celé univerzity, byl i přes svou politickou a pracovní vytíženost poměrně plodným autorem, jak je vidět na Spunarově seznamu dochovaných rukopisů ${ }^{1}$ a jak ukazují nové kritické edice, které se podařilo v posledních dvou desetiletích vydat. ${ }^{2}$ Křšst'an se zajímal převážně o obory kvadrivia a o medicínu, a právě v rámci jeho lékařských textů se naskýtá ještě řada témat, která by měla být důkladněji zpracována. ${ }^{3}$ Jedním $\mathrm{z}$ nich je problematika morových spisů dochovaných pod Křišt’anovým jménem, kterou se pokusíme otevřít jak touto drobnou studií, tak edicí dotyčných textů, jež následuje v př́loze.

Pod Křrišt’anovým jménem jsou zatím evidovány tři latinské morové texty, které byly doposud známé vždy v jediném opisu (pořadí uvedeno dle Spunara): ${ }^{4}$

* Článek vznikl v rámci projektu Grantové agentury České republiky 14-06134S „Latinský Herbář Kř̀išt’ana z Prachatic".

1 Pavel SpUnAR, Repertorium auctorum Bohemorum provectum idearum post universitatem Pragensem conditam illustrans, I, Wrocław etc. 1985, s. 123.

2 KŘıŠ̌̌Tan Z Prachatic, Základy aritmetiky - Algorismus prosaycus, ed. Zuzana SilagiovÁ, Praha 1999; KŘIǏŤAn z Prachatic, O poušténí krve - De sanguinis minucione, ed. Hana Florianová-MišKovsKá, Praha 1999; KŘiššan z Prachatic, Stavba a užití astrolábu, edd. Alena Hadravová - Petr Hadrava, Praha 2001. Starší edice uvádí P. SpunAR, Repertorium, I, 1. c. O jeho životě a díle píše zatím nejobšírněji Alena Hadravová ve zmíněné edici (s. 13-29), kde je i bohatý seznam odborné literatury.

3 Zatím nejdůkladněji se Křišt’anovým lékařským spisům věnuje Gustav GeLLnER, Jan Černý a jiní naši lékaři do konce doby jagellovské, in: Věstník Královské české společnosti nauk, tř. 1., roč. 1934, část III, 1935, s. 2-94, 148-153.

4 P. SpunaR, Repertorium, I, s. 117-118. 
1. Remedium reportatum, incipit In ista peste sive pestilencia non est melius nisi fugere loca pestifera, Praha, Národní knihovna ČR, IX A 4 (f. 168vå-169ra), prèelom 14. a 15. století; ${ }^{5}$

2. Contra pestilenciam consilium magistri Cristanni, incipit Primo fugere loca pestilentica, Brno, Moravská zemská knihovna, Mk 94 (f. 196v-197r), začátek 16. století; ${ }^{6}$

3. Regimen in pestilencia, incipit Quia pestilencie in nostris sepius eveniunt terris, Bratislava, Slovenská akadémia vied, 392 (f. 94v-95v), 1. polovina 15. století. ${ }^{7}$

Remedium reportatum vyšlo jako jediné z uvedených textů tiskem, a to v rámci Sudhoffových morových studií, vydávaných řadu let v časopisu Archiv für Geschichte der Medizin..$^{8}$ Atribuce Křištanovi je uvedena v explicitu: Explicit remedium reportatum per magistrum Cristianum. Na začátku se tu dává obligátní rada vyhýbat se nakaženým místům, jídlu i pití. Před každým jídlem se má užívat jako antidotum dryák (tyriaca) z červené hlinky, díky němuž se jídlo, pokud je nakažené, vyzvrací, poté dryák zvaný tyriaca magna; je však nutné se řádně vypotit, at již $\mathrm{v}$ posteli či v teplé koupeli a pot důkladně utř́it nahřátou látkou. Následuje recept na protimorové electuarium (lektvar) a návod, jak užívat protimorové pilulky mistra Mikuláše. ${ }^{9} \mathrm{Na}$ konci čteme krátké poučení o pouštění krve, k němuž má dojít co nejdříve po zjištění nákazy. Hovoří se tu pouze o dvou místech, kde se objevují hlízy v podpaží a v tř́ślech. Velmi důležité je, že text doporučuje pouštět žilou vždy na opačné straně těla, než na které se objevila hlíza. Na rozdíl od většiny jiných morových naučení se zde vůbec nehovoří o tom, jaké potraviny se v době moru doporučují k jídlu. Jak Spunar, tak Sudhoff datují zápis rokem 1409. K této dataci se dostaneme později.

Zápis druhého morového pojednání byl pořízen Matyášem Šustem roku 1516 v Novém Městě pražském a je opatřen titulem Contra pestilenciam consilium magistri Cristanni. ${ }^{10}$ Spunar uvádí rozsah consilia až do folia 205v. Konec je však ohlášen celkem jasně slovem explicit již na f. 197r a následující pasáže se již moru vůbec netýkají. Obsah consilia zcela odpovídá tehdy běžným radám, jeho první část se soustředí na prevenci, druhá na terapii. U flebotomie se zmiňují všechna tři místa, na nichž se hlízy objevovaly (v podpaží, pod ušima, v tříslech). Od konce f. $197 \mathrm{r}$ do f. $205 \mathrm{v}$ jsou uvedeny převážně recepty na složené léky proti dně, je tu popis několika různých příčin tohoto onemocnění, následuje návod na výrobu čípků, tak zvaná znamení smrti (tj. popis příznaků, podle nichž lze usuzovat, že člověk umírá) a návod na důkladné pročištění trávicího traktu, kdy se má dotyčný zdržovat doma (pobližz „toalety“) dokonce celé dva dny. Odkaz na Křišt’ana tu již nenacházíme a není tu ani žádná větší souvislost s recepty proti dně a popisem znamení smrti, jak je

5 Josef TRUHLÁR̆, Catalogus codicum manu scriptorum Latinorum, qui in c. $r$. bibliotheca publica atque universitatis Pragensis asservantur, II, Pragae 1906, s. 2; digitální kopie dostupné v databázi <www.manuscriptorium .com> (24. 7. 2017).

6 Vladislav DoKoupIL, Soupis rukopisů mikulovské dietrichsteinské knihovny, Praha 1958, s. 160-163; Adolf PATERA, Bohemika knižeci dietrichsteinské knihovny v Mikulově, Praha 1915, s. 46-47; rukopis dostupný rovněž v databázi <www.manuscriptorium.com> (24. 7. 2017). Další dochovaný opis viz níže.

7 Július SoPKo, Stredoveké latinské kódexy v slovenských knižniciach-Codices Latini medii aevi bibliothecarum Slovaciae, Martin 1981, s. 149-150, č. 135; také tento kodex je dostupný online: <http://oldbooks.savba.sk /digi/Rkp_zv_392/start.htm> (24. 7. 2017).

8 Karl SudHofF, Pestschriften aus den ersten 150 Jahren nach der Epidemie des ,schwarzen Todes“ 1348, VI, Prager Pesttraktate aus dem 14. und dem Anfange des 15. Jahrhunderts, Archiv für Geschichte der Medizin (dále AGM) 7, 1913, s. 57-114, zde s. 100-101. Text znovu otištěn v př́loze 1.

9 Viz níže, pozn. 70

10 Edice v př́loze 3. 
čteme v Lékařských knižkách, ${ }^{11} \mathrm{i}$ když ani taková souvislost by nemohla postačovat jako důkaz Křišt'anova autorství. ${ }^{12}$ Vše ukazuje spíše na jeho prítele a kolegu Albíka z Uničova, protože dole na foliu 203v čteme odkaz na recepty, které lze najít in Italico et in compendio in registris. Takovou informaci by si Albík docela dobře mohl poznamenat, nebot' studoval v Itálii práva a jistě ho zajímaly i tamější lékařské texty. ${ }^{13} \mathrm{Na}$ f. $203 \mathrm{r}$ je dále zapsán recept na mast, kterou údajně užíval král Václav, a léčba dny je důležitým tématem v Albíkových regiminech pro Lucemburky (jak pro Václava IV., tak pro Zikmunda Lucemburského). ${ }^{14}$ V brněnském rukopisu se navíc dochoval také Albíkův protimorový spisek Libellus de preservacione a peste..$^{15}$ Spunarově pozornosti uniklo, že opis téhož morového regimina - rovněž s titulem Contra pestilenciam consilium magistri Cristanni - našel Bohumil Ryba také v rukopisu strahovském DG IV 13 na f. $70 \mathrm{v}-71 \mathrm{r}$ z 15 . století; ${ }^{16}$ po něm hned navazují tytéž předpisy proti dně, pouze závěrečná poznámka o dalších receptech in Italico et in compendio in registris byla radována (f. 73v), díky brněnskému rukopisu je však text rozluštitelný. ${ }^{17}$

Konečně posledním morovým spisem, který Spunar uvádí, je Regimen in pestilencia, dochované v jediném rukopisu, tentokrát datovaném do roku $1430 .{ }^{18}$ Opět je tu jasná atribuce Incipit regimen magistri Cristanni in pestilencia. I zde se postupuje od profylaxe $\mathrm{k}$ terapii, dává se několik možností, jak se chránit pomocí léků a vhodných jídel (rozlišuje se přitom mezi chudými a bohatými, což je v tomto žánru obvyklé), doporučuje se vykuřovat dům, brát protimorové pilulky, dělat důkladnou vnitřní očistu těla, vyjmenovávají se vhodná a nevhodná jídla. Poté se již autor věnuje pouštění žilou, jako doplněk rovněž navrhuje užít dryák a vypotit se. Stejně jako u Remedia, také zde se zmiňují pouze dvě místa, kde bývají hlízy (podpaží, tř́sla). Tento spisek jako jediný rozlišuje mezi denními dobami, kdy se objeví první hlíza - na tom totiž závisí doba, kdy se má pouštět žilou a uživat dryák.

11 Širší veřejnosti je Křišstan znám především díky těmto Knižkám. K dispozici je přetisk starého tisku z roku 1553, který vyšel pod názvem Lékařské knižky Mistra Křištana z Prachatic z mnohých vybrané, ed. Zdeňka Tichí, Praha 1975. Tento tisk je však z větší části tvořen tzv. Jádrem, které se v rukopisné tradici vyskytovalo v širší podobě. Jako Lékařské knižky Křišt’ana z Prachatic je v některých rukopisech označován jiný lékařský sborník, tzv. kompilace neznámého františkána, kterou zhruba reprezentuje edice Alena ČERNÁ (ed.), Staročeské knihy lékařské, Brno 2006.

12 Jsou tu obsahové shody u dvou receptů a znamení smrti dle Galéna. Srov. A. Černá (ed.), Staročeské knihy, s. 86 a 155. O nějaké závislosti tu ale nemůže být řeč. Takové recepty putovaly ze sbírky do sbírky, různě se rozšiřovaly a zestručňovaly, některé jejich ingredience mohly být nahrazovány jinými apod. Pro př́buznost takových textů by tedy měly být nalezeny pádné důkazy.

13 Najít tento recept v Albíkových spisech jsem se nepokoušela. Pro poučení o jeho životě a díle viz Milada ŘíHovÁ, Dvorni lékař poslednich Lucemburků, Praha 1999. Aktualizovaný seznam všech zatím známých rukopisů vydal Bernhard Schnell, Albich von Prag. Arzt und Erzbischof im Zeitalter der Hussiten, in: Václav Bok - Hans-Joachim Behr (Hgg.), Deutsche Literatur des Mittelalters in und über Böhmen, II, České Budějovice/Budweis 2002, Hamburg 2004, s. 237-264.

14 M. Ř́ínová, Dvorní lékař, s. 113, 120.

15 Spisek vyšel i tiskem: Ivana Firlová - Pavla LutovsKÁ - Alena SKIPALovÁ, Př́spěvek k léčení moru v pozdně středověkých Čechách (Na základě spisủ Albika z Uničova), Historická demografie 11, 1987, s. 21-50, zde s. 31-47.

16 Bohumil Ryвa, Soupis rukopisů Strahovské knihovny Památníku národního písemnictví v Praze, III, Strahovské rukopisy DF-DG (̌̌. 1236-1821), Praha 1979, s. 402-404.

17 Rukopisy se liší pouze dvěma různočteními, která v edici uvádím v poznámce pod čarou (viz příloha).

18 Rok 1430 je uveden na f. 69v (stejnou rukou jako text morového regimina). Na f. $102 \mathrm{v}$ je datace 1429 opět stejnou rukou, rok se ale vztahuje spíše ke vzniku daného traktátu než k jeho opisu (explicit tractatulus... 1429 editus...). Edice v príloze 2. 
Četností rad se tedy blíží consiliu, ale každé radě je tu věnováno více prostoru - např. zdůvodněním léčebných postupů nebo vysvětlením jejich účinků.

Všechny tři texty mají samožrejmě jisté obsahové shody. Ty jsou dány tím, že prakticky veškeré morové písemnictví druhé poloviny 14 . a první poloviny 15 . století vychází z dobrozdání, které vydali mistři pařížské lékařské fakulty v roce 1348 (Compendium de epidimia per collegium facultatis medicorum parisius ordinatum).${ }^{19}$ Tam najdeme poměrně podrobně zpracovány tehdejší názory na príčiny této choroby a doporučení ohledně prevence i léčby. ${ }^{20} \mathrm{Ve}$ většině morových pojednání se napřr. radí nechodit př́lišs na veřejnost, především se vyhýbat veřejným lázním, doporučuje se jíst protimorové pilulky, vykuřovat ložnici vonnými bylinami, jíst kyselé potraviny, mít veselou mysl atd. Bez závažných formulačních shod a podobnosti v uspořádání látky nelze tedy na bližší př́ibuznost textů usuzovat. $\mathrm{Z}$ tohoto pařǐžského dobrozdání potom vychází další důležitý morový text, tzv. Missum imperatori (Contra pestilenciam missum imperatori) Havla ze Strahova z roku 1371, rukopisně značně rozšířený a velmi oblíbený pro svoji stručnost a přehlednost. ${ }^{21}$ Jeho rady jsou číslovány a texty odtud pocházející zpravidla zachovávají toto číslování, př́padně přidávají nové očíslované paragrafy do textu i na jeho konec. Missum imperatori bylo východiskem nejen pro další latinská zpracování, ale stojí také na počátku tradice morových spisů psaných v němčině, která začíná právě v Praze, jak v poslední době ukazují především Gundolf Keil a Bernhard Schnell. ${ }^{22}$

19 Vydáno bylo několikrát, např. H. Émile RÉBouıs, Étude historique et critique sur la peste, Paris 1888. Dostupné online na $<$ http://www.biusante.parisdescartes.fr/histoire/medica/resultats/index.php?do=livre\&cote =70399> (24. 7. 2017). Podrobný obsah viz Bernhard Schnell, Prag und die Anfänge der deutschen Pestliteratur im Mittelalter, in: Ralf G. Päsler - Dietrich Schmidkte, Deutschsprachige Literatur des Mittelalters im östlichen Europa: Forschungsstand und Forschungsperspektiven, Heidelberg 2006, s. 483-501, zde s. 485-488.

$20 \mathrm{~K}$ tehdejším představám o šíření moru podává základní poučení Klaus Bergdolt, Pest, in: Werner E. Gerabek - Bernhard D. Haage - Gundolf Keil - Wolfgang Wegner, Enzyklopädie Medizingeschichte (dále EM), III, Berlin - New York 2007, s. 1122-1127, zde také seznam monografí́ k morové tematice. V českém překladu vyšla monografie Klaus Bergdolt, Černá smrt v Evropě. Velký mor a konec středověku, Praha 2002. Z původních českých prací je třeba zmínit Eduard Wondrák, Historie moru v českých zemích, Praha 1999. Několik novějších specializovaných monografií o moru uvádí i Milada ŘíHovÁ a kol., Lékaři na dvoře Karla IV. a Jana Lucemburského, Praha 2010, s. 26, pozn. 95. Pro další literaturu viz také Martin NodL, Lékař a mor, aneb intelektuál rezignujíci i bojujicí, Listy filologické 124, 2001, s. 252-276, zde s. 260-261, a Karel ČERNÝ, Mor 1480-1730. Epidemie v lékařských traktátech raného novověku, Praha 2014, s. 27-33.

21 Několik různých dokladů vydal Sudhoff, např. Karl SudHoff, Ein weiteres deutsches Pest-Regiment aus dem 14. Jahrhundert und seine lateinische Vorlage, das Prager Sendschreiben „Missum Imperatori“ vom Jahre 1371, AGM 3, 1910, s. 144-153, zde s. 149-150. Nejlépe je pracovat s edicí u Gloria WerthmanN-HaAs, Altdeutsche Übersetzungen des 〉Prager Sendbriefs (»Missum imperatori «). Auf Grund der Ausgabe von Andreas Rutz neu bearbeitet, Würzburg 1983, s. 30-32, která rozděluje text na 16 paragrafů (jeden paragraf odpovídá jedné větě).

22 Gundolf KeIL, Der Pest->Brief an die Frau von Plauen in einer ostmitteldeutschen Fassung des Spätmittelalters. Ein Beitrag zur altschlesischen Fachprosa (in Form eines Briefes an den Herausgeber), Schlesien. Eine Vierteljahresschrift für Kunst, Wissenschaft und Volkstum 36, 1991, s. 138-145, zde s. 139; TÝž, Chirurgische Fachprosa des 13. bis 15. Jahrhunderts in Schlesien, Nordmähren und Nordböhmen, in: R. G. Päsler - D. Schmidkte, Deutschsprachige Literatur, s. 387-426; B. Schnell, Prag und die Anfänge, s. 483-501. Literatura k německy psaným morovým spisům je poměrně bohatá. Základní přehled o nejstarších a nejrozšířenějších textech podává (kromě právě uvedených př́íspěvků z roku 2006) G. WERTHMANN-HAAS, Altdeutsche Übersetzungen, s. 16-30. Vztah mezi nejstaršími německými morovými návody a Missum imperatori je tedy přesně opačný, než uvádí Jana Nechutová, Latinská literatura českého středověku do $r$. 1400 , Praha 2000, s. 226. 
Tři dochované latinské morové texty, které jsou Křišt’anovi prripisovány, jsou od sebe natolik odlišné, že vzbuzují pochybnosti o jednom jediném autorovi. Na druhou stranu ale můžeme počítat s tím, že se Křišt’an jako literárně aktivní lékař a jako učitel medicíny k dané problematice nějak vyjádřil, nebot' s morem byl konfrontován každý praktikující lékař té doby. Proto také byl tento žánr, označovaný většinou jako morové traktáty ${ }^{23}$ či morová regimina, velmi populární. Protimorových návodů bylo tehdy v oběhu nespočetné množství a díky tomu ještě v dnešní době najdeme jejich exempláře bohatě zastoupeny ve všech tradičních evropských knihovnách. Většina z nich samozřejmě nebyla doposud vydána, a proto není tento žánr zatím důkladně zpracován, alespoň v př́ípadě textů latinských. Daleko lépe je na tom tzv. Pestliteratur, německá pojednání o moru, i když i tam je jejich poznání vzhledem k počtu dochovaných spisů spíše v počátcích. ${ }^{24}$ Dle Schnella totiž němečtí medievisté, vycházející především z dokladů, které zveřejnil Sudhoff, zatím systematicky nestudovali katalogy českých rukopisných knihoven. ${ }^{25}$ Je pravděpodobné, že budoucnost přinese mnoho nových zjištění, a již proto zde může být pouze naznačeno, jakým směrem by se bádání mělo prozatím ubírat. Křrišt’anovské texty by měly být především porovnány se staršími latinskými morovými texty, alespoň s těmi, které byly v Praze prokazatelně dostupné nebo zde mají svůj původ, dále s texty německými - jednak kvůli existenci pojednání zvaného Theriak-Pesttraktat, o němž bude ještě řeč, ${ }^{26}$ a jednak proto, že některá německá regimina byla překládána do latiny, ${ }^{27}$ a konečně se staročeskými morovými texty, které se zpravidla tradovaly v různých lékařských sbornících (s Křištanovým jménem se můžeme setkat především v Jádru a v tzv. kompilaci neznámého františkána, jak ukázal David Tomíček ve své důkladné excerpci asi tří desítek takových rukopisů). ${ }^{28}$

I přes značnou nepřehlednost, která asi ještě nadlouho zůstane typickým znakem dochovaných písemných morových památek, a přes jistou šablonovitost v jejich návodech, můžeme přece jen sledovat určité rozdíly. Některé návody jsou zpracované systematicky a čtenář se na začátku dozví, jak je text členěn a podle toho se také dále postupuje (text se zpravidla rozpadá do dvou nebo tří hlavních částí - prevence, léčba, prrípadně příčiny nákazy, prevence, léčba), v rámci prevence se potom někdy postupuje podle sex res non naturales, které jsou zapsány v pořadí, na jaké jsme zvyklí u regimin sanitatis. Tato důkladná pojednání však nebyla těmi nejrozšířenějšími. Hojně se opisovaly především stručné návody o několika větách, které často jakoukoli systematičnost postrádají. Některé návody začínají terapií a končí prevencí (ve shodě s Missum imperatori), jiné postupují přesně opačně (ve shodě s dobrozdáním pařížských mistrů). Další zřretelné rozdíly jsou v radách na pouštění žilou. Nejčastěji vycházejí tyto spisy z reálného stavu, kdy se hlízy objevují na třech místech na těle a tomu také odpovídají tři místa pro pouštění žilou (to je opět zřetelná závislost

23 Pro řadu těchto drobných pojednání to není přesné označení, nebot' se jedná o velmi stručné návody o několika větách, proto Werthmann-Haas užívá název „Kurztraktat“ (G. WerTHMANN-HAAS, Altdeutsche Übersetzungen, s. 15).

24 Pro studium tohoto žánru jsou dodnes východiskem vydání Sudhoffova (Karl SudHoff, Ein deutsches Pest-Regiment aus dem 14. Jahrhundert, AGM 2, 1909, s. 379-383; TÝž, Ein weiteres deutsches Pest-Regiment; TÝž, Pestschriften aus den ersten 150 Jahren nach der Epidemie des ,, schwarzen Todes “1348, I, AGM 4, 1911, s. 191-222, 389-424, a další ročníky téhož časopisu až do roku 1925.

25 B. Schnell, Prag und die Anfänge, s. 498.

26 K němu G. KeIL, Chirurgische Fachprosa, s. 387-426.

27 Keil upozorn̆uje na prípad Dopisu paní z Plavna (G. KeIL, Der Pest->Brief, s. 138).

28 David Tомі́̈̌ек, Vira, rozum a zkušenost v lidovém lékařství pozdně středověkých Čech, Ústí nad Labem 2009, s. $71-75$. 
na Missum imperatori), případně hovoří pouze o dvou místech na těle pro minuci, a to podle toho, zda je hlíza v horní části těla, či ve spodní (což je ve shodě s pař́̌žským dobrozdáním). Některé texty však vyjmenovávají i řadu jiných míst (prsa, záda), kde ve skutečnosti morové hlízy nevznikají. ${ }^{29}$ Rozdíl také spočívá v doporučení, zda pouštět krev na stejné straně těla, kde vznikla hlíza, či na straně opačné. Někdy se doporučují vystrúídat obě dvě strany v závislosti na vitalitě a věku pacienta. Nejčastěji se setkáme s prvním případem, vycházejícím z Missum imperatori. Regimina, která jsou na Missum imperatori založena, bud' zachovávají jeho číslování, případně ho doplňují, nebo číslování zcela vypouštějí a nechávají rady plynout jednu za druhou. Způsob zpracování i obsah těchto spisů a spisečků je tedy vysoce variabilní, přestože se většina rad opakuje stále dokola. Míra systematičnosti a hojnost informací je vždy závislá na cílovém čtenáři, pro kterého byl předpis určen. Dochovaly se převážně prakticky zaměřené předpisy určené pro vzdělané laiky a dále předpisy pro lékaře, nejmenší skupinou jsou odborná pojednání vzešlá z univerzitní výuky, zabývající se touto problematikou na teoretické úrovni (např. metodou scholastických kvestií).

Pro všechny tři křišt’anovské texty je charakteristické jejich praktické zaměření. Začínají preventivními opatřeními, teprve poté se vyjadřují k léčbě. Ve flebotomii se věnují pouze reálným místům na těle. Jednotlivé rady nejsou číslovány. Kromě těchto základních ukazatelů jsou ale po formální i obsahové stránce dost odlišné. Formou se vymyká především Contra pestilenciam consilium brněnského a strahovského rukopisu, které je velmi stručné a ze všech tří textů má nejblíže k Missum imperatori, ve flebotomické části se s ním v podstatě zcela shoduje. Text je kratší než Missum imperatori, ale nemusel nutně vzejít prímo z něho, spíše se jedná o stručné výpisky z nějakého jiného naučení, silně závislého na Missum imperatori. Právě tento text vzbuzuje největší pochybnost ohledně Křišt’anova autorství, a proto jej otiskuji na posledním místě. Podobně banální seznam rad si mohl vypracovat jakýkoli laik. Spunar považuje Consilium za jinou recenzi pražského Remedia. ${ }^{30}$ Srovnání obou textů jisté shody vykazuje, především u rady, která praví, co má člověk ráno preventivně pozřít, pokud chce jít ven do nakaženého prostředí, nicméně jiné rady Consilia jsou zase bližší Missum imperatori. Možnost, že by Consilium vzniklo zestručněním Remedia či naopak Remedium rozpracováním Consilia můžeme v každém př́ípadě vyloučit.

Zbývající dva latinské křišt’anovské texty obsahují propracovanější návody, než jaké má Havlův list (a eo ipso i Consilium). V prŕípadě pražského Remedia jsou to podrobné návody na pocení, Regimen bratislavského kodexu zase zevrubně vysvětluje časový rozvrh pro pouštění žilou a následné užívání dryáku. Tyto pasáže zřejmě odrážejí zkušenosti praktikujícího lékaře. Každý ze spisů je koncipován jinak. Remedium se zabývá pouze jedním způsobem, jak se lze chránit před morem, a to je užití správných protilátek ve formě složených léků (antidota). Regimen naopak nabízí komplexní seznam rad, v němž užívání léků tvoří pouze jednu část. Tento text lze na rozdíl od prvního považovat za ucelené pojednání. Faktické odlišnosti nejsou tak zásadní, že by musely být oba texty s jistotou označeny za dílo dvou různých osob, lze si však představit i autora jediného, který sepsal tyto texty s větším časovým odstupem. Jak vyplyne z následujícího výkladu, kloním se zatím k názoru, že tu

29 Je to typické pro některé německé návody, které byly velmi rozšířené (tzv. Sendbrief-Aderlaßanhang a Dopis pani z Plavna, B. Schnell, Prag und die Anfänge, s. 494-495.

30 P. Spunar, Repertorium, I, s. 118, č. 307. 
máme co dělat s autory dvěma a že Křišt’an z Prachatic může být autorem pouze bratislavského Regimina.

Nyní se však zaměříme především na Remedium reportatum, nebot' jeho zápis v pražském kodexu IX A 4 si jednak zaslouží komentář a jednak bylo toto pojednání díky Sudhoffově vydání identifikováno německými medievisty jako předloha pro jeden německý překlad. Kodex IX A 4 je jedním z deseti dochovaných svazků Husova stoupence a prŕtele Šimona z Rokycan (upálen roku 1421). ${ }^{31}$ Do jinak výhradně filozoficky a teologicky orientovaného kodexu si Šimon vlastnoručně zapsal na f. $168 v^{\mathrm{a}}$ až $169 \mathrm{v}^{\mathrm{b}}$ krátký exkurz do oblasti medicíny. Dvě strany jsou popsány třemi morovými texty, poslední strana obsahuje lékařské verše. Prvním morovým textem je Missum imperatori, druhým je právě Remedium reportatum a konečně třetí text je anonymní a podává poučení o pouštění žilou a léčení hlíz, aniž by se o moru nějak výslovně zmiňoval. I tento text vydal Sudhoff. ${ }^{32}$ Jak jsme již řekli, Sudhoff i Spunar uvádějí jako datum zápisu rok 1409, od Sudhoffa převzal tento údaj zřejmě také Gellner, Šmahel a Nodl. ${ }^{33}$ Sudhoff vycházel z marginálního doplňku, který stojí na místě, kde končí Missum imperatori a začíná Remedium reportatum. Tento marginální doplněk vypadá graficky následovně: que erant de anno domini $M^{\circ} C C C^{\circ} 9^{\circ}$ post festum Sancti Bartholomei, nikoli tedy $C C C^{\circ}$, a Sudhoff ho přiřadil k začátku Křišt'anova Remedia za slova In ista peste sive pestilencia, kam se velmi dobře hodí a plurál erant se tu vzhledem k onomu zdvojenému peste sive pestilencia dá tolerovat. Ve skutečnosti však písařská značka jasně ukazuje, že dodatek patří k předchozí větě, která ukončuje Missum imperatori odkazem na jeho autora, Havla ze Strahova - Remedium datum per magistrum Gallum contra apostemata pestilentica. Marginálii přriřadil písař za adjektivum pestilenti$c a, \mathrm{i}$ když je celé vyjádření poněkud neobvyklé. Ještě podivnější je však datování do roku 1309, které musí být nutně chybné, ale je otázkou, v čem ona chyba spočívá. Rok 1409 by jistě vyhovoval, navíc vynechání jednoho století je chyba, s níž se setkáváme u středověkých datací velmi často. Nepodařilo se mi však najít údaje o tom, že by v tomto roce řádil v Praze mor. ${ }^{34}$ Ke stejnému závěru došel i Nodl, který proto rok 1409 chápe ,„pouze jako orientačni"، ${ }^{35} \mathrm{Na}$ f. 196r však čteme dataci do roku $1403 \mathrm{v}$ grafické podobě $14^{\circ} 3^{\circ}$, tj. nula v letopočtu má stejné postavení jako indexové „o“, které má naznačovat koncovku ablativu 1. deklinace. Grafický záznam $M^{\circ} C C C^{\circ} 9^{\circ}$ můžeme tedy s jistotou číst jako $1390,{ }^{36}$ kteréžto datum dobře zapadá i do dalších kodikologických souvislostí. Za prvé si kodex uchovává stále svoji původní vazbu a zmíněná datace 1403 je uvedena na pořadově pozdějším foliu než údajný rok 1409, dle mého názoru však 1390. Za druhé byla větší část kodexu psána na stejném papíře jako jiný Šimonův svazek, který je datován již rokem $1401 .{ }^{37}$ V roce 1409 tedy zřejmě nevznikl ani Šimonův zápis, natož text v exempláři, který

31 Milada SvobodovÁ, Dochované kodexy z knihovny M. Šimona z Rokycan († 1421), in: Jitka Radimská (ed.), $\mathrm{K}$ výzkumu zámeckých, měšt’anských a církevních knihoven. Čtenář a jeho knihovna - Pour une étude des bibliothèques aristocratiques, bourgeoises et conventuelles, České Budějovice 2003, s. 13-30, ke kodexu IX A 4 na s. 24-27.

32 K. SUdHOFF, Pestschriften, VI, s. 102-103.

33 G. Gellner, Jan Černý, s. 65; František Šmahel, Husitská revoluce, II, Kořeny české reformace, Praha 1993, s. 23; M. NoDL, Lékar̆ a mor, s. 262.

34 Srov. M. Vojtová a kol., Déjiny československého lékařství, I, Do r. 1740, Praha 1970, s. 150-151.

35 M. NodL, Lékař a mor, s. 262.

36 Rovněž Svobodová četla tento letopočet jako 1409 bez jakéhokoli komentáře, přestože znala podobu datace 1403 (M. Svobodoví, Dochované kodexy, s. 24, 26).

37 Tamtéž, s. 24. 
si Šimon opisoval. Důležité je, že v roce 1390 v Praze mor opravdu byl a není vyloučeno, že Havel ze Strahova byl ještě na živu. ${ }^{38}$ Poslední zprávu o něm máme z roku $1388 .{ }^{39}$ Missum imperatori se datuje sice již do roku 1371, ale další vlna moru, která prrišla v roce 1389, jistě podnítila vznik nových opisů. V každém př́padě se rok uvedený v marginálii vztahuje k Missum imperatori, nikoli k Remedium reportatum.

I když není pochyb, že explicit Remedium datum per magistrum Gallum contra apostemata pestilentica patří k předchozímu Missum imperatori, je třeba mu věnovat několik vět. Jeho umístění je totiž matoucí - začíná po skočení Missum imperatori na novém řádku a bezprostředně za ním, nikoli až na novém řádku, začíná Remedium reportatum slovy In ista peste. Nebýt obsahu, graficky vše vypadá tak (včetně užití rubriky), jako by měl být uvozením textu následujícího. Tento dojem dané místo činilo i na humanistického písaře, který zaznamenal obsah kodexu na předním př́́deští následujícím způsobem: „... $4^{\circ} \mathrm{M}$. Galli Remedium contra apostemata pestilentica a folio 168 verso usque ad folium 169, 50 M. Christani remedium contra Apostemata in folio 169 versum..." Údaj o Havlovi zcela jasně vztahoval na Křrišt’anovo Remedium reportatum, které začíná již na $168 v^{\mathrm{a}}$ a které končí nahoře na f. 169ra. Podobně i moderní popis kodexu, který je $\mathrm{k}$ dispozici v databázi Manuscriptorium, chápe tři morové texty jako jedinou obsahovou jednotku, kterou člení na tři části, přičemž věta Remedium datum per magistrum Gallum je přiřazena k části druhé, tj. k textu údajně Křřštanovu. Ten je, jak již bylo řečeno, ukončen větou Explicit remedium reportatum per magistrum Cristianum. Truhlář vyř̌šil matoucí atribuci Havlovi elegantně a píše souhrnně o Remedia contra apostemata pestilentica MM. Galli et Cristanni.$^{40}$ Zmínka o Havlově autorství však jednoznačně patř́ k Missum imperatori, již proto, že větu na konci druhého morového textu nelze vztáhnout $\mathrm{k}$ textu třetímu, jak správně argumentoval Sudhoff. ${ }^{41}$ Stejně jako explicit k Missum imperatori začíná za textem na samostatném řádku, je za druhým morovým textem explicit o Kř̀išt’anovi zapsán rovněž na novém řádku. Písař jen nešt’astně začal psát Křišstanovo Regimen na stejném řádku, na kterém hovoří o autorovi textu předchozího.

Ačkoli marginální datace do roku 1390 patří k Missum imperatori, samožrejmě to neznamená, že ji nelze vztáhnout i na text bezprostředně následující. Tento rok a závěrečné spojení reportatum per magistrum Cristianum totiž lákají k různým hypotézám. Spunar i Sudhoff automaticky chápali Křišt’ana jako autora Remedia. Spojení reportatum per však ukazuje, že by se mohlo v tomto př́padě jednat o opis textu, který si Křišt’an pořídil v době svých jinak nedoložených, ale předpokládaných studií medicíny. Právě sloveso reportare a odtud substantiva reportaciones či reportata se běžně užívaly pro studentské zápisy z přednášek. ${ }^{42}$ Remedium reportatum by tak bylo dílem Křrištanova

38 K jeho osobě naposledy M. RínovÁ a kol., Lékaři, s. 169-175. Mor z roku 1390 potvrdil výzkum E. Maura (Eduard Maur, Mory v Praze 1348-1419 ve svétle úmrtnosti farního kléru, Documenta Pragensia 7, 1987, s. 145-159, zde s. 150, dále srov. Ludmila Fialová, Déjiny obyvatelstva českých zemí, Praha 1998², kapitola II, Obyvatelstvo českých zemí ve středověku od Eduarda Maura, s. 35-73, zde s. 62).

39 M. Ř́novÁ a kol., Lékaři, s. 169 a dále 170-171.

40 Viz pozn. 5.

41 K. Sudhoff, Pestschriften, VI, s. 72.

$42 \mathrm{~K}$ pojmům reportatio, reportare viz např. Jacque Verger, Vorlesungs- und Predigtnachschrift, in: Robert-Henri Bautier - Robert Auty u. a. (Hgg.), Lexikon des Mittelalers, VIII, München 1997, sl. 1852-1853; Olga Weijers, Terminologie des universités au XIII siècle, Roma 1987, s. 361-365, TÁž, Le maniement du savoir. Pratiques intellectuelles à l'époque des premières universités (XIII -XIVe siècles), Turnhout 1996, s. 145-152; 
učitele. Původní zápis mohl vzniknout v roce 1390, kdy Křišt’an ukončil mistrovskou zkouškou studium na artistické fakultě a mohl se hned pustit do studia lékařství. ${ }^{43}$ Ve svých záznamech (snad šlo o volné listy) mohl mít zapsáno i Missum imperatori jakožto základní protimorovou poučku. Šimonova kopie Křišt’anových záznamů je nesmírně důležitým dokladem - Šimon jakožto Husův blízký přítel totiž musel osobně znát i Křišt'ana, a proto je velmi pravděpodobné, že si zápis reportace zapůjčil přímo od něho. Díky tomu je opis prost chyb, které vznikají při delší písemné tradici. ${ }^{44}$ Proto bych raději mluvila o Křišt’anově reportaci než o Křišt’anově remediu. Že jde o zápis z přednášky, by mohla ukazovat jeho torzovitost, respektive specializace pouze na dvě vybraná témata související s morem (užití protiléků a flebotomie).

Naskýtá se otázka, čí přednášku mohl Křišt’an zapisovat. Sudhoff si povšimnul, že Remedium reportatum se nápadně shoduje s jiným morovým textem, Remedium ... in pestilencia, které otisknul na základě berlínského rukopisu Lat. Fol. 88, připisujícího Remedium mistru Havlovi. ${ }^{45}$ Obě Remedia mají místy shodné formulace a stejné je i pořadí jednotlivých rad. Berlínský text je ale stručnější a vypadá jako výtah textu pražského. Docela dobře si lze představit, že Remedium reportatum opravdu pochází od Havla ze Strahova. S názorem, že by Křišt'an byl Havlovým žákem, se sice v odborné literatư̌e téměř nesetkáme, výjimka tu však je (bohužel bez odkazu na pramen), a to Spěváčkova monografie o Karlu IV., kde se tvrdí, že Havel ze Strahova „patrně vychoval Křištana z Prachatic“". ${ }^{46}$ Chronologické překážky tu zřejmě nejsou - za prvé je docela dobře možné, že Havel byl ještě v roce 1390 naživu, a za druhé, pokud bychom počítali s rokem 1388, po kterém již o něm nemáme zmínku, jako s rokem jeho smrti, nelze vyloučit, že Křišt’an chodil na přenášky z medicíny již před skončením svého magisterského studia v roce 1390. Podmínkou pro studium medicíny totiž byl bakalářský stupeň ve studiu artes. ${ }^{47}$ Působení Havla ze Strahova na univerzitě je kvůli celkovému nedostatku pramenů k počátkům lékařské fakulty doloženo sice jen pro rok $1371,{ }^{48}$ je ale nesporné, že zde jako učitel působil dlouhodobě. ${ }^{49} \mathrm{~K}$ Havlovi lze navíc dodat ještě jednu poznámku: V bratislavském kodexu, který Sudhoff neznal, je

Mariken TEeuwen, The Vocabulary of Intellectual Life in the Middle Ages, Turnhout 2003, s. 333-335, zde další literatura.

43 P. Spunar, Repertorium, I, s. 116; Karel BerÁneK, O počátcích pražské lékařské fakulty 1348-1622. De facultatis medicae Pragensis initiis, Acta Universitatis Carolinae - Historia Universitatis Carolinae Pragensis (dále AUC-HUCP) 9/2, 1968, s. 44-87, zde s. 77.

44 Všechny chyby mohly vzniknout již v provní kopii. Trojí dittografie ukazuje na nepozornost písaře. Vážnější chyba je záměna „collacio“ za „collamento“, které zřejmě stálo v předloze. Obě slova vypadají ve zkrácené podobě stejně a záleží pouze na tom, zda písař rozlišuje graficky „,c“a „„““. Nominativ collacio zrejmě při psaní zarazil i Šimona, tak podtečkoval předložku ,de“.

45 K. Sudhoff, Pestschriften, VI, s. 71-72. K rukopisu Valentin Rose, Verzeichniss der Lateinischen Handschriften der Königlichen Bibliothek zu Berlin, II, Die Handschriften der Kurfürstlichen Bibliothek und der Kurfürstlichen Lande, Dritte Abteilung, Berlin 1905, s. 1088-1098.

46 Jiří SPĚvÁČEK, Karel IV. Život a dílo (1316-1378), Praha 1979, s. 377.

$47 \mathrm{~K}$ běžnému postupu studia František ŠMAHEL, Mistři a studenti pražské lékařské fakulty do roku 1419, AUC-HUCP 20/2, 1980, s. 35-68, zde s. 46; K. BERÁNeK, O počátcích, s. 47-49. Šimon sice píše, že Křišt’an je magister, ale tento údaj se může vztahovat k době, kdy vznikl jeho zápis, nikoli k době, kdy vznikla reportace.

48 Srov. F. S̆ MAHEL, Mistři a studenti, s. 44. V revidovaném otisku téže studie je Havel uveden v tabulce mezi mistry lékařské fakulty v letech 1359-1371, ale v jeho medailonu se píše, že Havlovo působení na univerzitě není doloženo vůbec (in: František ŠMahel, Alma mater Pragensis. Studie k počátkưm Univerzity Karlovy, Praha 2016, s. 138 a 146).

49 V pražském prostředí se jednalo o běžnou praxi - královští lékaři současně vyučovali na univerzitě. 
bezprostředně za Křišt’anovým textem na f. $95 \mathrm{v}$ zapsán recept na electuarium in pestilencia mistra Havla ze Strahova a týž recept je součástí pražského Remedium reportatum..$^{50} \mathrm{~V}$ berlínském výtahu, kde je Remedium připsáno výslovně Havlovi, však recept chybí. Zatím není možno vynášet konečné soudy, tato drobnost jen ukázuje, že křištanovské morové texty nelze zkoumat bez znalosti jiných pražských latinských morových spisů té doby, především těch, které se dochovaly pod Havlovým a Albíkovým jménem..$^{51} \mathrm{~V}$ rukopisech se totiž morová naučení neobjevují izolovaně, ale bývá jich zpravidla opsáno více za sebou, mnohdy najdeme pohromadě latinské i vernakulární záznamy. Tato situace potom mohla vést $\mathrm{k}$ chybně opsaným atribucím.

Jméno Albíka z Uničova nás pozvolna posouvá $\mathrm{k}$ německé tradici morových spisů, která se nabaluje na Křišt'anovo jméno. Spunar eviduje (jako dubium) pouze jeden německy psaný morový spisek, dochovaný ve vídeňském rukopisu Lat. 14545 (Österreichische Nationalbibliothek, f. $5 \mathrm{v}-12 \mathrm{v}) .{ }^{52}$ Text opět vydal Sudhoff, ${ }^{53}$ kterému neušlo, že jeho začátek má svou latinskou paralelu v Albíkově regiminu Vetularius, určeném pro Václava IV. ${ }^{54}$ Po této shodné pasáži následuje popis znamení smrti (neshoduje se se znameními v rukopisu Mk 94, ani se staročeskou verzí znamení smrti v Lékařských knižkách, které se Křřšt'anovi připisovaly) a na konci jsou vyjmenovány konkrétní potraviny, jimž se má člověk vyhýbat, uvedeny slovy Hyr ynne so rothe ich meyster Cristannus, ale ani u této závěrečné pasáže nenajdeme žádné zásadní shody se třemi křišt’anovskými latinskými spisy. Označení dubium tu tedy rozhodně zůstává v platnosti.

Zcela odlišný německý protimorový text představuje tzv. Theriak-Pesttraktat (psáno též jako Theriak-Pest-Traktat), ${ }^{55}$ který německá odborná literatura často uvádí jako Křišt’anův (někdy se mluví o ne zcela potvrzeném autorství). ${ }^{56}$ Tento Morový traktát o dryáku pojmenoval jeho vydavatel Emil Höring. Název má zdůraznit význam, který toto pojednání připisuje dryáku, a to jak v prevenci, tak v terapii. Höring připravil edici na základě tehdy

50 Recept koloval i samostatně, Sudhoff ho našel (jen s drobnými úpravami) zapsaný v jednom wolfenbüttelském rukopisu bezprostředně za morovým regiminem, které odtud přepsal včetně receptu (srov. K. SuDHOFF, Pestschriften aus den ersten 150 Jahren nach der Epidemie des „,schwarzen Todes “ 1348, XIII, Ausarbeitungen über die Pest nach der Mitte des 15. Jahrhunderts aus Nieder- und Mitteldeutschland, AGM 14/1-2, 1922, s. 1-25, zde s. 10). S malými obměnami je recept rovněž na dvou místech jednoho vratislavského rukopisu (K. SudHofF, Pestschriften aus den ersten 150 Jahren nach der Epidemie des ,schwarzen Todes “ 1348, X, Pesttraktate aus Böhmen, Schlesien und Nachbarbezirken bis zur Mitte des 15. Jahrhunderts, AGM 9, 1916, s. 117-167, zde s. 160 a 163). Př́prava lékủ samotnými lékaři byla v té době zcela běžnou praxí, která je doložena i u mistra Havla (M. RínovÁ a kol., Lékaři, s. 170).

51 Jedná se především o Regimen tempore pestilencie, dochované jednak jako samostatný spis a jednak jako 9. kapitola regimina pro krále Václava IV. Vetularius. Spis koloval v několika různých verzích, o nichž povšechně referují Ivana Firloví - Pavla Lutovská - Alena SkiPalová, Př́spěvek k problematice léčení moru v pozdně středověkých Čechách (na základě spisů Albíka z Uničova), Documenta Pragensia 7/1, 1987, s. 174-192, zde s. 174-175. Spunarovo členění Albíkových morových naučení do tří položek (č. 243, 245, 246) je nevyhovující (srov. P. SPUNAR, Repertorium, I, s. 106-107).

52 Hermann Menhardt, Verzeichnis der altdeutschen literarischen Handschriften der österreichischen Nationalbibliothek, III, Berlin 1961, s. 1367-1368.

53 K. SudHofF, Pestschriften, VI, s. 104-105, uvádí chybnou signaturu 15545, kterou má patrně odtud i Spunar. Oba rovněž uvádějí jiný - menší - rozsah folií (liší se od sebe navzájem i od údaje v katalozích). Znám tento text pouze v rozsahu vydaném Sudhoffem.

54 Tamtéž, s. 104, pozn. 2.

55 G. KeIL, Chirurgische Fachprosa, s. 393, 394, 396.

56 Základní údaje viz encyklopedická hesla Gundolf KeIL, Christian von Prachatitz, in: Kurt Ruh u. a. (Hg.), Die deutsche Literatur des Mittelalters. Verfasserlexikon, I, Berlin - New York 1978, sl. 1222-1223; TÝž, Theriak, in: EM III, s. 1394; Christoph WeIsSER, Christian von Prachatitz, in: tamtéž, I, s. 260. 
známých čtyř rukopisů. ${ }^{57}$ Poté byly zjištěny ještě tři další doklady, nová plánovaná kritická edice však bohužel nevyšla. ${ }^{58}$ Jelikož nebyl nikde otištěn kompletní seznam všech doposud známých rukopisů a jelikož Spunar toto německé znění vůbec nezmiňuje, vyplatí se podat jejich přehled zde. Dnes je známo deset rukopisů. První čtyři rukopisy jsou zohledněny v Höringově edici, ostatní byly objeveny později (č. 5-7 uvádí G. Werthmann-Haas, ${ }^{59}$ č. 8-10 uvádí B. Schnell se svými spolueditory): 60

1. München, Bayerische Staatsbibliothek, cgm 725 (f. 13r-14r), incipit In dem sterben ist nicht pesser den die stat oder stett zu fliechen do der sterb ist); 61

2. soukromá sbírka Gerharda Eise (Privatsammlung Eis, Schriesheim u Heidelbergu, cod. 54, f. 10r-11r, dnes ztracený); ${ }^{62}$

3. Heidelberg, Universitätsbibliothek, cpg. 577, f. 11r-12v;

4. Nürnberg, Germanisches Nationalmuseum, 18792, f. 179r-180r;63

5. München, Bayerische Staatsbibliothek, clm. 17296, f. 84r;

6. München, Universitätsbibliothek, 825, f. 5v-6v;

7. Nürnberg, Germanisches Nationalmuseum, 198354, f. 27r-28v;

8. München, Bayerische Staatsbibliothek, cgm 728 (f. $42 \mathrm{v}-43$ r); ${ }^{64}$

9. Wolfenbüttel, Herzog-August-Bibliothek, Cod. Guelf. 79 Aug. $2^{2}$, f. $182 \mathrm{v}-183 \mathrm{v} ;{ }^{65}$

10. Wien, Österreichische Nationalbibliothek, 2826 (f. 182v-183v). ${ }^{66}$

Text Höringovy edice dle čtyř rukopisů (v seznamu na prvním místě) a také znění rukopisu vídeňského (znění zbývajících rukopisů neznám) odpovídá latinskému Remedium reportatum, tj. máme zde skutečně co dělat se dvěma jazykovými verzemi téhož pojednání. Z jazykových znaků Höring vyvodil, že text mohl vzniknout ve středním Bavorsku nebo ve Švábsku, a protože se tu zmiňují pilulky mistra Mikuláše, kterým má být dle Höringa myšlen lékař Nicolaus vom Schwert působící ve Švábsku (na přelomu 14. a 15. století),

57 Emil HöRING, Der schwäbische Theriak-Pesttraktat von 1389, Medizinische Monatsschrift 30, 1976, s. 308-311.

58 G. Werthmann-HaAs, Altdeutsche Übersetzungen, s. 22.

59 Tamtéž, s. 22.

60 Viz níže u jednotlivých rukopisů.

61 Karin SchneIder, Die deutschen Handschriften der Bayerischen Staatsbibliothek München: Cgm 691867. Editio altera, Wiesbaden 1984, s. 147. Incipity ostatních rukopisů neuvádím, většinou nemají velké odchylky.

62 K tomuto rukopisu Gerhard EIs, Meister Alexanders Monatsregeln, Lychnos. Jahrbuch der schwedischen Gesellschaft für Geschichte der Wissenschaften 1950-1951, s. 104-136, zde s. 111; edice Gerhard Eis (Hg.), Zur deutschen Pestliteratur des 15. Jahrhunderts, Medizinische Monatsschrift 6, 1952, s. 321-323 (na základě obou heidelberských rukopisů, jiné Eisovi známy nebyly).

63 K tomuto rukopisu: Gerold Hayer - Bernhard Schnell (Hgg.), Johannes Hartlieb ,Kräuterbuch ', Wiesbaden 2010, s. 41-42.

64 K. SCHNEIDER, Die deutschen Handschriften der Bayerischen Staatsbibliothek München: Cgm 691-867, s. 160, k rukopisu také Bernhard Schnell - William Crossgrove (Hgg.), Der deutsche Macer. Vulgatfassung. Mit einem Abdruck des lateinischen Macer Floridus „,De viribus herbarum “, Tübingen 2003, s. 192-193.

65 Johannes Hartlieb ,Kräuterbuch', s. 43-44.

66 Rukopis je dostupný online na webových stránkách Österreichische Nationalbibliothek <http://www.onb .ac.at/> (24. 7. 2017). Dále k němu Johannes Hartlieb ,Kräuterbuch', s. 43. V příslušném katalogu není text uveden jako samostatná jednotka, a není proto dle incipitu dohledatelný (srov. Hermann MENHARDT, Verzeichnis der altdeutschen literarischen Handschriften der österreichischen Nationalbibliothek, I, Berlin 1960, s. 391). 
lze vznik textu umístit právě tam. ${ }^{67}$ Höring neměl tušení, že pro tento text existuje latinská předloha připisovaná Křišt’anovi z Prachatic, proto jej považoval za původní německé pojednání. ${ }^{68}$ Novější literatura pokládá za místo vzniku německé verze Prahu ${ }^{69}$ a pilulky mistra Mikuláše mají ve skutečnosti svůj původ ve spisu Antidotarium Nicolai, ${ }^{70}$ o němž bude řeč níže. Jistý vztah mezi Křšst'anovou reportací v němčině, tedy Morovým traktátem o dryáku, a švábským lékařem Mikulášem však přece jen existuje - Mikuláš totiž použil tento traktát jako pramen pro svoje vlastní německy psané morové pojednání. ${ }^{71}$ Kromě toho našel Gundolf Keil ještě další dva doklady jeho využití. Prvním je jedna z pozdějších redakcí Dopisu paní z Plavna (Brief an die Frau von Plauen), zapsaná ve vratislavském kodexu I F 334 (f. 299v-300r). Byl sem převzat jeden odstavec, díky němuž lze dle Keila stanovit spodní časovou hranici pro vznik této redakce. Není však jasné, kde tuto hranici vidí, nebot' uvádí (bohužel bez udání pramene) rok 1405 jako rok, odkdy se Křišt’an začal věnovat spisovatelské činnosti, ${ }^{72}$ a jednak upozorňuje vykřičníkem na datum v názvu Höringova článku (Der schwäbische Theriak-Pesttraktat von 1389), ${ }^{73}$ v němž byl Theriak-Pesttraktat kriticky vydán. K těmto rozporuplným údajům se nijak nevyjadřuje. Druhý př́pad využití německého znění najdeme u Ulricha Rüleina von Kalbe († asi 1523) v jeho morovém pojednání Underweysung wie man sich tzu der tzeit der pestilenz halten sol, vydaném tiskem pár let před smrtí autora. ${ }^{74}$ Konečně třetí morové pojednání, které je třeba v rámci tzv. druhého života Křišt’anovy reportace zmínit, bylo zapsáno v jednom harburském kodexu, který je dnes rozdělen na kodexy dva (Harburg, Bibliothek der Fürsten Öttingen-Wallerstein, Cod. III 1, $8^{\circ}$ 58, a Cod. III 2, 80 34). ${ }^{75}$ Zde je z větší části opsán Theriak-Pesttraktat, ale v závěru text obsahuje změny a další př́ídavky. Pojednání o pouštění žilou je nahrazeno př́íslušnou pasáží z Dopisu paní z Plavna a na ně navazuje ještě odstavec s dalšími radami a recepty. Zde se původní text reportace uplatnil jako pramen ve větší míře než u předchozích dvou dokladů (tvoří více než polovinu celého pojednání). ${ }^{76}$ Nutno podotknout, že samotný Dopis paní z Plavna bývá dokonce někdy Křrišt’anovi připisován. ${ }^{77}$

Oklikou přes německou verzi se tak dostáváme zpět k dataci Křišt’anovy latinské reportace. Vznik německé verze klade Höring, jak již bylo uvedeno, do roku 1389, což vyvozuje

67 E. Höring, Der schwäbische Theriak-Pesttraktat, s. 308. K tomuto lékaři viz Gundolf KeIL, Nicolaus vom Schwert, in: EM II, s. 1048-1049. Různé starší pokusy o identifikaci tohoto Mikuláše viz G. EIs, Zur deutschen Pestliteratur, s. 322.

68 Na tuto skutečnost jej na poslední chvíli upozornil Gundolf Keil a Höring ji již nestihl do úvodu k edici zapracovat (E. HöRING, Der schwäbische Theriak-Pesttraktat, s. 311, pozn. 53).

69 Viz pozn. 22.

70 G. KeIL, Nicolaus, s. 1049.

71 Tamtéž, s. 1048; G. KeIL, Chirurgische Fachprosa, s. 398, pozn. 71.

72 G. KeIL, Der Pest->Brief, s. 143, pozn. 22.

73 Tamtéž, pozn. 21. Rok 1398, který má Keil, považuji za tiskařskou chybu.

74 Gundolf KeIL - Johannes G. MAYer - Monika ReInINGer, „Ein kleiner Leonardo “. Ulrich Rülein von Kalbe als Humanist, Mathematiker, Naturwissenschaftler und Arzt, in: Gundolf Keil (Hg.), Würzburger Fachprosa-Studien. Beiträge zur mittelalterlichen Medizin-, Pharmazie- und Standesgeschichte aus dem Würzburger medizinhistorischen Institut, Würzburg 1995, s. 228-247, zde s. 232.

75 K obsahu rukopisu důkladně Volker Zimmermann, Rezeption und Rolle der Heilkunde in landessprachigen handschriftlichen Kompendien des Spätmittelalters, Stuttgart 1986, s. 24-28, na s. 83-84 k př́islušnému morovému traktátu, který obsahuje Křišt'anovu reportaci.

76 Text vydal Zimmermann tamtéž (s. 130-132, k textu samotnému s. 83-84), dává jej do souvislosti s rukopisy heidelberskými, jejichž edici pořídil Eis, ale Höringovu edici neznal a práci Glorie Werthmann-Haas v této souvislosti také necituje, přestože ji k dispozici měl.

77 Srov. G. KeIL, Christian von Prachatitz, sl. 1223. 
ze závěrečného odstavce, který je tu navíc oproti verzi latinské. ${ }^{78}$ Zde se tvrdí, že mor řádí již čtyřicet dva let. Je otázkou, zda tento překladatel mohl mít povědomí o tom, že se mor v Evropě poprvé objevil v roce 1348. Pokud ano, snad mínil bud' rok 1389, nebo i rok 1390, o němž byla řeč u latinské verze reportace. Při počítání rozdílu let, uběhnuvších od roku 1348 do roku 1390, lze snadno zapomenout započítat první rok. Spíše se však můžeme domnívat, že počítal s rokem, kdy se morová epidemie objevila v místě, kde žil. Vlna, která začala roku 1348, se na Moravu dostala v roce 1349 a do Čech až 1350, ale nebyla tak ničivá. Daleko silněji potom mor udeřil v roce $1357,{ }^{79}$ i tento rok mohl tedy překladatel chápat jako počátek epidemie. Všechny rukopisy se navíc v tomto údaji neshodují - vídeňský rukopis 2826 píše pouze o čtyřiceti letech, která uplynula od počátku morové nákazy (f. 183v). Každý nový doklad tedy může přinést nové poznatky.

K jazykovým znakům, které vznik překladu posouvají do Bavorska či Švábska, se musí kompetentně vyjádřit germanisté, jazykové znění některých rukopisů se však výrazně odlišuje od znění vydaného Höringem. Keil i Schnell zmiňují Theriak-Pesttraktat vždy v souvislosti s nejstaršími německými morovými spisy, a ty mají svůj původ v pražském prostředí. ${ }^{80}$ Švábské jazykové rysy nemusejí být nutně překvapivé, uvědomíme-li si, že Praha mohla mít jistá pojítka se švábským prostředím např. v osobě Johanna Sueva (Švába) de Monte Leonum (Löwenberg), který na lékařské fakultě v Kř̌šs'anově době působil. Oba mistři jsou jmenováni v anonymní rekomendaci, jejíž děkovný závěr vydal Sudhoff dle jednoho lübeckého rukopisu. ${ }^{81}$ Vzhledem k univerzitní dráze Johanna Sueva (Jana Švába), který byl služebně starší než Křišt’an (roku 1386 se již objevuje jako magister in medicina $)^{82}$ nelze vyloučit, že předtím, než se oba lékaři stali kolegy, byli ve vztahu učitel-žák, jehož produktem mohla být Křrišt’anova latinská reportace. I tato úvaha, stejně jako možnost, že se jednalo o zápis přednášky Havla ze Strahova, je však ryze hypotetická a nelze jí přisuzovat větší platnost. V této době na lékařské fakultě působila i řada dalších lékařů, pro rok 1388, kdy mohl Křišt'an začít se studiem nejdříve, jich je doloženo minimálně pět, pro rok 1390, který je pro začátek jeho lékařského studia pravděpodobnější, víme o čtyřech. ${ }^{83}$

Čeho si nelze v německé odborné literatuře nevšimnout, je zdůrazňování nezvyklých terapeutických postupů, které se v Křrišt’anově reportaci objevují. Mluví se o nich samozřejmě v souvislosti s jejím německým překladem, ale ten věrně odráží svou latinskou předlohu. Tato tvrzení se tedy vztahují i na ni. Specifičnost údajně spočívá jednak ve výrazném užití

78 Je to jediný přídavek, nemají ho však všechny rukopisy. Jinak německá verze neobsahuje nic, co by současně nebylo součástí verze latinské. Některá místa však byla v německém překladu vypuštěna či zjednodušena. Největší rozdíl spočívá v absenci receptu, který bratislavský rukopis připisuje mistru Havlovi („,electuarium pestilenticum secundum magistrum Gallum“) a který je do latinské reportace zahrnut (viz pozn. 50).

79 L. Fialoví, Dějiny, s. 61 a 62.

80 Viz pozn. 22.

81 K. SudHofF, Pestschriften aus den ersten 150 Jahren nach der Epidemie des ,schwarzen Todes “ 1348, XV, Pesttraktate aus dem östlichen Süddeutschland, Böhmen und Österreich in der 2. Hälfte des 15. Jahrhunderts, AGM 14/5-6, 1923, s. 129-168, zde s. 157: „Nunc venio ad vltimum videlicet ad graciarum actiones... regracior doctori egregio hiuius(!) facultatis medicine decano magistro Johanni de Monte Leonis... et deinde regracior magistro meo reuerendo magistro Christiano de Prachatiz de fauore et promocione multifaria..." (zachovávám grafickou podobu dle Sudhoffa).

82 F. ŠMAHEL, Mistři a studenti, s. 58. K němu také František Michálek BARToš, Proslulý lékař Karlovy university věku Husova, Jihočeský sborník historický 13, 1940, s. 37.

83 F. ŠmahEL, Mistři a studenti, s. 44. 
dryáku (jak k prevenci, tak v terapii), kterým se škodliviny odvádějí z těla ven, ${ }^{84} \mathrm{v}$ následném pocení na lůžku či v teplé lázni a důkladném osušení suchou teplou látkou a jednak v pouštění žilou na opačné straně těla, než se nacházejí hlízy. ${ }^{85}$ Pravdou je, že Missum imperatori výslovně hovoří o pouštění ze stejné strany těla a o koupání jako prostředku k pocení se nezmiňuje vůbec. Protože velké množství morových naučení vychází právě z Havlova listu, je logické, že se s tímto návodem setkáváme velmi často. Lze však nalézt řadu textů, které více či méně korespondují naopak s předpisy reportace. V pařížském dobrozdání se sice také nedoporučuje koupat se v teplé vodě, nebo aspoň méně často, než je člověk zvyklý (summa 2 , tract. 1, cap. 2), ${ }^{86}$ stejně jako se tu nepraví nic o důležitosti pocení, ale dryáku z červené hlinky je přisuzován velký význam (summa 2, tract. 2, cap. 2) ${ }^{87}$ a tzv. velký či pravý dryák je uveden na prvním místě mezi antidoty (tamtéž). ${ }^{88}$ Při pouštění žilou se hovoř́ o možnosti využít bud' jednu, nebo obě paže (summa 2 , tract. 2 , cap. 1 ) ${ }^{89}$ připouští se tedy i pouštění žilou na straně opačné. Silný důraz na používání dryáku a protimorových pilulek najdeme např. $v$ druhé části morového traktátu vydaného ve středověké nizozemštině Braekmanem a Dogaerem dle rukopisu pařížské Bibliothèque national (Ms. fr. 9136, f. $372 v-374 v$ ). Dle editorů vznikly tyto pasáže pod vlivem rad pařížského dobrozdání. ${ }^{90}$ I v korpusu textů, které vydal Sudhoff, najdeme shodné terapeutické postupy - dle regimina dochovaného $\mathrm{v}$ mnichovském kodexu clm 259 (f. 180r) se po dryáku má jít do koupele a vypotit se a po koupeli se znovu vypotit. ${ }^{91} \mathrm{~V}$ regiminu rukopisu Národní knihovny I G 23 (f. 160r-160v) se doporučuje pouštět žilou z opačné strany těla, než je hlíza, a také se klade důraz na pocení, i když ne po dryáku, ale po jiném antidotu (princip je ovšem stejný - antidotum odvádí škodliviny z těla ven prostřednictvím pórů). ${ }^{92} \mathrm{O}$ pocení se zmiňují i návody lipského rukopisu 1129, jednou týdně ráno na lačno má člověk kvůli prevenci užít dryák a vykoupat se. ${ }^{93} \mathrm{~V}$ regiminu dalšího rukopisu Národní knihovny I F 11 se radí provádět flebotomii stř́ídavě na opačné i stejné straně těla. ${ }^{94}$ Můžeme ovšem zůstat v Křišt’anově okolí - v Albíkově De regimine pestilencie se také dočteme o dryáku a pocení, člověk si má lehnout, dobře se přikrýt a vypotit, po pocení se dobře utř́t; krev se má pouštět na opačné straně těla. ${ }^{95}$ Vše to jsou doklady zjišš̌né spíše náhodou, bez cílené a systematické rešerše. Ve stručnější podobě než v reportaci najdeme tyto předpisy také v bratislavském rukopisu s Křišt’anovým Regimen in pestilencia. Dle mého názoru nelze tvrdit, že se jedná o léčebný koncept vlastní především Křišt’anovi z Prachatic. Spíše by se dalo uvažovat obecně o pražském prostředí - $\mathrm{v}$ rámci přednášek na lékařské fakultě se mohl stejné zásady na

${ }^{84} \mathrm{~K}$ použití dryáku jako prostředku proti morové nákaze viz především Thomas Holste, Der Theriakkrämer. Ein Beitrag zur Frühgeschichte der Arzneimittelwerbung, Würzburg 1976, s. 32-38, na s. 38 se zmiňuje Theriak-Pesttraktat.

85 G. KeIL, Chirurgische Fachprosa, s. 398; G. KeIL, Der Pest->Brief, s. 145, pozn. 40.

86 H. Émile RéBouss, Étude historique, s. 102.

87 Tamtéž, s. 24, 26

88 Tamtéž, s. 26. Pocení po jeho užití se tu možná nezdůrazňuje jen proto, že se jednalo o rutinní postup.

89 Tamtéž, s. 118.

90 Willy L. Braekman - G. Dogaer, Spätmittelniederländische Pestvorschriften, in: Gerhard Baader - Gundolf Keil (Hgg.), Medizin im mittelalterlichen Abendland, Darmstadt 1982, s. 443-475, zde s. 474.

91 K. SudHOFF, Pestschriften, VI, s. 62.

92 Tamtéž, s. 74.

93 Tamtéž, s. 76, 77.

94 Tamtéž, s. 81.

95 Tamtéž, s. 93; dle jiných rukopisů vydaly I. Firlová - P. Lutovská - A. Skipalová, Přispěvek k léčení moru, s. 39, 40, 41, srov. Také түтÉž, Př́spěvek k problematice léčení moru, s. 179. 
přelomu 80. a 90. let 14. století naučit od svého učitele jak Albík, ${ }^{96}$ tak Křrišt’an, kteří mohli lékařskou fakultu navštěvovat ve stejné době, a oba je dále propagovali.

K bližšímu poznání tří křrišt’anovských morových textů psaných latinsky nepochybně přispěje jejich zařazení do kontextu staročeských morových naučení. V odborné literatuře doposud nebyla těmto souvislostem věnována větší pozornost, známo je v podstatě jen to, co nabízí Spunarův seznam. Na tomto místě opět půjde jen o revizi a aktualizaci tohoto seznamu na základě dostupné odborné literatury. Rukopisy se staročeskými morovými texty uvádí Spunar jednak u pražského Remedia (u brněnského Consilia a bratislavského Regimina neznal překlady žádné), a jednak mezi staročeskými spisy Křišt’ana z Prachatic, u nichž paralelu k latinským textům nenašel. Začneme tedy se skupinou čtyř staročeských rukopisů, vyjmenovaných u latinského Remedia v domnění, že se jedná o jeho překlady. Všechny obsahují tzv. Zprávu proti šelmovému času, která vyšla dvakrát tiskem - nejprve ve Výboru z české literatury doby husitské97 (zde pod Křišt’anovým jménem), a poté v edici Staročeské knihy lékařské A. Černé (jako součást tzv. kompilace neznámého františkána). ${ }^{98}$ Tato iuxtapozice v Repertoriu je však mylná a Křrišt’anovi jsou tak připisovány výroky a návody, jež od něho nepocházejí. Z premisy, že Křišt’an je autorem Zprávy vycházeli v poslední době např́. Gojda 99 či Nodl, který sice pro svou antropologicky zaměřenou studii čerpal primárně ze Zprávy, ale jak z jeho textu vyplývá, znal i znění latinského Remedia. ${ }^{100}$ Tím více udivuje, že si nepovšimnul zásadních rozdílů mezi oběma texty. Samotná Zpráva proti šelmovému času totiž není př́ekladem ani volným zpracováním Remedia, ač tu drobné obsahové shody jsou. ${ }^{101}$ Jedná se o dvě různá pojednání. Zpráva navíc obsahuje radu, že se má užívat „prach mistra Křišt’ana“, což samo o sobě svědčí o tom, že jako celek od Křišt’ana nepochází. Rovněž s Consiliem a bratislavským Regiminem nemá tato Zpráva závažnější shody. Spolu se Zprávou se ve sborníku neznámého františkána tradoval i jiný morový text, který bývá nadepsán Když jest mor v které krajině, kterak máš živ býti, tyto věci zachovávaj... (incipit Najprvé aby se varoval těch miest, kdež mor jest). ${ }^{102}$ Ani ten nelze klást do souvislosti s křišt’anovskými latinskými naučeními. Jak Zpráva proti šelmovému času, tak Když jest mor v krajině rozpracovávají rady z Missum imperatori (druhý z textů má k Havlovu listu blíže). Většina těchto doplňkových informací obsahově vychází z pařížského dobrozdání, i když to jistě nebylo přímým pramenem. Zajímavá je shoda

96 Albík byl sice o pár let starší, ale v druhé polovině 90 . let studoval ještě práva. Lékařskou fakultu navštěvoval zřejmě v letech 1389-1394 (srov. přehled M. ŘínovÁ, Dvorni lékař, s. 23). Gerhard Eis se domníval, že Albík byl Křišt’anovým učitelem, a proto je Křišt’anovo morové regimen závislé na příbuzném spisu Albíkově (Gerhard EIs, Die sudetendeutsche Literatur des Mittelalters, in: Týž, Kleine Schriften zur altdeutschen weltlichen Dichtung, Amsterdam 1979, s. 409-458, zde s. 443).

97 Bohuslav HavráneK - Jiří DaňHelka - Josef HrabÁK (edd.), Výbor z české literatury doby husitské, II, Praha 1964, s. 574-575.

98 A. ČERnÁ (ed.), Staročeské knihy, s. 35-36. Ne všechny rukopisy však obsahují totožné znění, jak upozornila Bedřiška WižĎÁlková, Glosy na okraj Lékařských knih mistra Křištana, in: Pavel R. Pokorný (ed.), Pocta dr. Emmě Urbánkové, Praha 1979, s. 475-503, zde s. 479, mluví zde ještě navíc o rukopisu Národní knihovny IV G 9 a o rukopisu Roudnické Lobkowiczké knihovny v Nelahozevsi VI Fe 7, které Spunar v této souvislosti neeviduje. Rovněž M. VoJTovÁ a kol., Dějiny, s. 131 a 132, považuje Zprávu za součást františkánova sborníku a do souvislosti s Křišt’anem ji nedává.

99 Jan GoJda, Černá smrt v českých zemích ve středověku, diplomová práce, Univerzita Karlova v Praze, 3. lékařská fakulta, Praha 2009.

100 M. NodL, Lékař a mor, s. 259-273.

101 Tuto chybnou informaci má i E. Wondrák, Historie moru, s. 25.

102 Edice A. ČERnÁ (ed.), Staročeské knihy, s. 37-38. 
v doporučení Zprávy, že člověk má užívat dryák a po něm se vypotit. Toto doporučení, jak jsme již řekli, bylo v Praze zřejmě oblíbené. O prímé závislosti Zprávy na latinských křrištanovských textech však samo o sobě svědčit nemůže. Tím samozřejmě není řečeno, že by zmíněné staročeské památky nemohly od Křišst’ana pocházet alespoň vzdáleně, př́padně v některých svých částech, jeho autorství je tu však nanejvýš pochybné a bylo by třeba ho podpořit validními důkazy.

Nechme stranou dva ze čtyř Spunarových staročeských rukopisů, a to ty, které obsahují sborník neznámého františkána. ${ }^{103} \mathrm{Z}$ hlediska dochovaných latinských morových textů jsou daleko zajímavější zbývající dva rukopisy - rukopis B 1497 krakovské Knihovny Muzea Czartoryských ${ }^{104}$ a rukopis pražské Knihovny Národního muzea II H 4. Tyto rukopisy obsahují nejen Zprávu proti šelmovému času, ale ještě jiný morový text, uvozený nadpisem Tuto znamenaj dobré kusy lékařské, když lidé mrú na hlizy (v krakovském rukopisu se jedná o s. 135-142, v pražském o s. 481-487). Toto naučení, jehož vlastní incipit zní Poněvadž často mor v našich zemích bývá, ponechal Spunar jako samostatnou položku mezi Křišt’anovými staročeskými spisy s údajem auctor operis incertus a zaznamenává k ní jednak rukopis knížat Czartoryských a jednak rukopis olomoucké kapituly č. 300 (f. 287v-288v). Uniklo mu tedy, že týž text je zapsán v rukopisu muzejním II H 4, ${ }^{105}$ ale především jej nespojil s Křišt’anovým latinským Regiminem bratislavského kodexu, které bylo nepochybně podkladem pro tento staročeský, a nutno říci poměrně věrný překlad. Pokud přijmeme bratislavskou atribuci, $\mathrm{v}$ uvedených třech staročeských kodexech se nám dochovalo skutečné Křišs’anovo dílko, což u většiny českých lékařských textů, které se $s$ jeho jménem tradovaly, ř́ci nemůžeme.

Jak v krakovském, tak v muzejním rukopisu následují ihned za morovým regiminem ještě recepty uvozené nadpisem Toto lékařství mistr Křištáan jest vydal proti neduhu svrchnímu a zprávu učinil, jakž jest psáno. U Spunara je najdeme pod č. 321 Recepty, recepta, remedia. ${ }^{106}$ Ukázka z textu vyšla spolu se Zprávou proti šelmovému času ve Výboru z české literatury doby husitské dle muzejního rukopisu, kde k ní byl editory doplněn titul Rady proti moru. ${ }^{107}$ Obsah níže uvedených návodů však v ničem nenapovídá, že by se měly týkat stravování v době moru. Již v úvodní pasáži, která vyšla tiskem, se píše „,v tvé krmě kaž klásti a vařiti petružel pro kámen"108 a také dále je velká část receptů uvozena slovy ,proti kameni“. Některé ingredience úvodní pasáže se sice považovaly za účinné i v boji proti morové nákaze (ocet, zázvor), ale jako celek se tato doporučení vůbec neshodují s běžnými protimorovými opatřeními. Jedná se o běžná dietetická doporučení, která od Křištana nepocházejí. Zápis, který se odvolává na svrchní neduh, neměl být ve skutečnosti nadpisem pro tyto recepty, ale byl původně explicitem $\mathrm{k}$ předchozímu morovému regiminu, které máme i v jeho latinské verzi potvrzeno jako Křišt'anovo, a teprve v delší opisovačské tradici byl mylně interpretován jako uvození textu následujícího.

103 Jedná se o rukopisy pražské Národní knihovny XVII B 18 a XVII D 10, další viz A. ČERnÁ (ed.), Staročeské knihy, s. 378, a Alena M. ČERNÁ, Staročeské názvy chorob, Praha 2009, s. 165-166.

${ }^{104} \mathrm{~K}$ jeho obsahu podrobně Alena M. ČERNÁ, Český lékařský rukopis ze sbirky knižat Czartoryských, Slovo a slovesnost 70/2, 2009, s. 113-127.

${ }^{105} \mathrm{Na}$ shody mezi oběma kodexy upozornila A. M. ČERNÁ, Český lékařský rukopis, s. 116-117. Muzejní kodex je dle ní opisem krakovského, at již př́mým, či nepřímým.

106 P. SPUNAR, Repertorium, I, s. 121.

107 B. HavráneK - J. DañHelKa - J. Hrabák (edd.), Výbor, II, s. 576-577.

108 Tamtéž, s. 576. 
Jestliže se zpětně podíváme na Spunarův seznam latinských morových pojednání, která jsou v rukopisech připsána tomuto velkému mudrci a lékaři, ${ }^{109}$ mnoho položek v něm nezůstalo. Consilium je třeba přiřadit k velkému množství receptů, které kolovaly pod Křišt’anovým jménem v době, kdy bylo opředeno velkou slávou a kdy se takovou atribucí měl podpořit význam daného receptu. $\mathrm{O}$ autorství praktikujícího lékaře se v tomto př́ípadě vzhledem ke stručnosti a jednoduchosti návodu dá důvodně pochybovat. Pražské Remedium reportatum lze považovat za zápis, který si Křištan pořídil za svých studií medicíny, a to především díky skutečnosti, že jeho opis vytvořil Šimon z Rokycan, Husův a jistě i Křišt’anův přítel, který musel znát okolnosti vzniku Remedia. Reportace kolovala také v německém překladu, a to jak pod jménem domnělého autora, tak i anonymně. Zda všechny dochované rukopisy obsahují týž překlad, bude třeba ověřit, potřebná je také nová edice textu na základě nedávno zjištěných rukopisů. Český překlad Remedia zatím není znám, tzv. Zprávu proti šelmovému času za něj nelze považovat v žádné z jejích redakcí, které se dochovaly. ${ }^{110}$ Bratislavské Regimen by jako jediné v sobě snad mohlo uchovávat duševní vlastnictví Křrišt’ana z Prachatic. Kodex je prokazatelně českého ${ }^{111}$ původu a najdeme v něm dataci do roku 1429 a 1430, ${ }^{112}$ což jsou roky, které se v kopiích Křišt'anových spisů objevují nápadně často, někdy doplněné o lokaci do Jindřichova Hradce (např. jen u spisu De sanguinis minucione je toto datum zapsáno hned v pěti kodexech). ${ }^{113}$ Je téměř jisté, že Křšst'an se v době svého pobytu mimo Prahu v letech 1427-1429114 intenzivně věnoval spisovatelské činnosti, případně podněcoval vznik nových opisů svých starších odborných pojednání. Pro uznání autenticity tohoto textu může hovořit také fakt, že flebotomická pasáž je obohacena o informace, které upřesňují dobu, kdy se má pouštět žilou v závislosti na době nástupu první hlízy. Jedná se sice o povšechné poučení určené pro laiky, ale i z této povšechnosti vysvítají zkušenosti skutečného lékaře, které nejsou samozřejmou součástí morových spisů tohoto rozsahu a určení. Následné doporučení ohledně dryáku a důkladného vypocení pacienta jsou pak plně ve shodě s tím, co se Křišt'an naučil za svých studií. Výše zmíněný Havlův recept, který je na závěr k textu připojen, se sem mohl dostat rovněž z Křišt'anovy iniciativy, nebot' je součástí pražské reportace. Český překlad Regimina se dochoval minimálně ve třech rukopisech. ${ }^{115}$

Je jisté, že systematický průzkum středoevropských rukopisných knihoven přinese řadu nových poznatků ke všem třem křišt’anovským textům. Lze předpokládat, že budou nalezeny další zápisy verze německé a staročeské, případně texty z nich odvozené. Problémem je především počet dochovaných písemných památek, nebot' jak praví Bernhard Schnell, ,im Grunde gibt es im 15. Jahrhundert kaum eine medizinische Handschrift, in der nicht auch eine Pestschrift tradiert ist". 116

\footnotetext{
109 Tak o Křišt’anovi mluví strahovský rukopis DA IV 6, f. 78v.

110 Srov. B. WižĎÁLKoví, Glosy na okraj, s. 479.

111 Obsahuje mj. velmi zajímavé pojednání o štěpování stromů, kde se mluví o několika lokalitách Čech a Moravy.

112 Viz pozn. 18.

113 KřIŠŤan z Prachatic, O poušténí krve, s. XLVII-XLVIII.

114 F. ŠMAHEL, Husitská revoluce, III, s. 118 a 216.

115 Kritická edice zatím pořízena nebyla, pro základní představu o podobě staročeského textu může sloužit transkribce rukopisu z knihovny Czartoryských od Aleny M. ČERNÉ a Kateřiny Volekové, Vokabulár̆ webový. Webové hnizdo pramenů k poznání historické češtiny, <http://vokabular.ujc.cas.cz/moduly/edicni/edice /fe3004d3-0ccf-4582-911d-5946c90fe154/plny-text/s-aparatem/folio/19> (24. 7. 2017); zde dostupný také přepis Křišt’anova morového regimina dle výše uvedeného rukopisu olomoucké kapituly CO.300.

116 B. Schnell, Prag und die Anfänge, s. 498.
} 
Přepis textů otištěných v př́lohách se řídí pravidly formulovanými Bohumilem Rybou. ${ }^{117}$ Všechny texty jsou zatím známy pouze z jednoho dochovaného rukopisu. Jeden z nich (reportace) sice již tiskem vyšel, ${ }^{118}$ považuji ale za užitečné, aby byly všechny tři texty vydány pohromadě. Při přepisu reportace jsem vycházela z rukopisného znění a Sudhoffovo čtení jsem na několika místech opravila. Všechny odchylky od Sudhoffova vydání (s výjimkou grafických jevů) ${ }^{119}$ jsou zaznamenány v kritickém aparátu. Do textu zavádím vlastní interpunkci. Pouze na jednom místě rozumím textu jinak než Sudhoff, a proto se neuchyluji k jeho emendaci, jen člením text odlišným způsobem.

\section{Seznam pramenů:}

Remedium reportatum: Praha, Národní knihovna ČR, IX A 4 (f. 168va-169ra)

Regimen in pestilencia: Bratislava, Slovenská akadémia vied, 392 (f. 94v-95v)

Contra pestilenciam consilium: Brno, Moravská zemská knihovna, Mk 94 (f. 196v-197r);

Praha, Knihovna Královské kanonie premonstrátů na Strahově, DG IV 13 (f. 70v-71r)

117 Jsou dostupná online na více místech, např. <http://is.muni.cz/el/1421/jaro2011/PV2B62/um/Ryba.pdf> (24. 7. 2017).

118 Viz pozn. 8 .

119 Sudhoff uplatňoval klasicizující pravopis. Jediná grafická odchylka, která si tu zaslouží zmínku, je přepis spojení „sub talo“ x „subtalo“. Sudhoff přepisoval v obou výskytech odděleně, v nové edici jsem se přiklonila ke spojenému zápisu. V prvním př́padě je slovo psáno na přechodu mezi dvěma řádky, ale písař jasně naznačil, že chápe slovo jako rozdělené, tj. nepovažoval „sub“ za předložku, celé spojení „de pede dextro subtalo“ nezní sice př́liš ladně, ale o pár řádků níže najdeme spojení „de subtalo pedis“, které jasně ukazuje, že se jedná o substantivum označující místo pod kotníkem. 


\section{Přiloha 1 - Remedium reportatum per magistrum Cristianum}

In ista peste sive pestilencia non est melius nisi fugere loca pestifera, quia sicut ${ }^{120}$ qui fugit ignem, ignis non sequitur eum, aut ${ }^{121}$ si non licet fugere nec locum mutare, tunc precavere debet ab omni cibo et potu, qui poterit infici. Unde remedium est uti de tyryaca de terra sigillata ante comestionem et ante bibicionem, quia ista medicina prodit pestilenciam et curat eam. Quia si quis /f. 169r $/$ sumit de ista medicina ante comestionem ad quantitatem unius nucis avelane, et sic si tunc sumit ${ }^{122}$ aliquod cibum infectum vel pestilenciale, statim cogitur illum evomere. Et hoc si tunc acciderit, tunc plus de ea sumat, quousque illum totum malum evomat, et tunc sumat post hoc de tyryaca mariori ad quantitatem unius dragme vel minus cum tali decoccione rute, salvie, enciane, aristulogie, ${ }^{123}$ baccarum lauri et tormentilla et herba tunicii, ${ }^{124}$ que alio nomine polimonion ${ }^{125}$ appellatur, et hec decoccio fiat in vino bono et post hoc colletur munde et tunc cum ${ }^{126}$ tali decoccione et collamento ${ }^{127}$ vini sumatur tyriaca modo [modo] consueto. Et si nollet balneari, tunc sumat in lecto iacendo ante auroram diei vel hora matutina et sudet in lecto et in fine faciat sudorem abstergere optime de toto corpore cum panno lintheo sive lineo bene calido, aut si vellet balneari, intret balneum sic in ieiunio nichil aliud sumendo preter tiriacam et sudaret in balneo in calore lento et semper abstergatur sudor cum panno calido in fine sudoris. Valet eciam in preservacione a tali peste tale electuarium: postea recipias nuces maiores $\mathrm{XX}$, ficuum mundorum $\mathrm{XV}$, rute manipulum, radicis genciane II et semis, aristologye longe I, salis conmunis ad quantitatem nucis, mellis purissimi, quantum sufficit, conficiantur ${ }^{128}$ in modum electuarii (aliqui addunt tormentillam et herbam tunicii ${ }^{129}$ et bene), de quo sumatur ieiuno stomacho ad quantitatem nucis avellane. Usus istius electuarii preservat a toxis et venenis. Uti eciam pillulis pestilencialibus multum iuvat et preservat ab aere infecto, uti eciam pillulis magistri Nicolai infra XV dies vel citra valet multum, quia ille pillule purgant malos humores et eciam venenosos, uti de tiriaca maiori, sicut modo prius scripsi, optimum est, et hoc infra $\mathrm{X}^{130}$ dies vel citra.

Quando contingeret, quod tamen deus [deus] dignetur precavere, quod illud apostema inciperet oriri, statim apponatur aut in illo loco vel prope ${ }^{131}$ inferius ventuosa cum scarificacione, ut extrahatur tota materia venenosa, et sangwis minuatur, ut si oriretur superius sub ascellis, tunc minuatur sagwis de parte opposita, ita quod si oriretur sub ascella sinistra, tunc minuatur sagwis de brachio dextro de vena epatica, et si oritur sub ascella dextra, tunc minuatur sagwis de brachio sinistro, et sic intelligatur de aliis partibus corporis. Et si oriretur apostema inferius sicut [in iguinie] in iguinibus, tunc si oritur in parte sinistra, tunc minuatur sagwis de pede dextro subtalo de vena zaphena, sicut mittunt conmuniter

\footnotetext{
120 sicut : sicuti Sudhoff

121 sequitur eum, aut : sequitur. Eum aut<em>Sudhoff

122 sumit : fuerit Sudhoff

123 aristulogie : astulogiae Sudhoff

124 tunicii : truncii [?] Sudhoff

125 polimonion : polimomen Sudhoff, polimomon $m s$.

126 cum supplevi: de deletum cum punctis suppositis in ms.

127 collamento : collacio $m s$.

128 conficiantur emendavi : conficeantur $m s$.

129 tunicii : truncii [?] Sudhoff

$130 \mathrm{X}$ omisit Sudhoff

131 prope : proprie Sudhoff
} 
mulieres, ut si oritur in parte dextra, tunc minuitur sagwis de subtalo pedis sinistri semper in parte opposita, ut distrahatur venenum sive materia venenosa ad partem oppositam. Et semper post minucionem neccesse est, ut /169ra/ sumatur tiriaca tempore suo sicud prius dixi et semper sola et per se nichil aliud sumendo cum ea usque post dissudacionem.

Explicit remedium reportatum per magistrum Cristianum 


\section{Příloha 2 - Regimen magistri Cristanni in pestilencia}

\section{Incipit Regimen magistri Cristanni in pestilencia}

Quia pestilencie in nostris sepius eveniunt terris, igitur pro aliquali a pestilentico morbo preservacio et curacio succincte infra scripta notentur.

Primo quod quicunque est in loco, ubi viget pestis seu pestilencia, bonum est, ut ieiunus aerem infectum aut homines infectos non visitet, nisi prius pro medicina conservativa recepit de confectu amaro, quem apotecarii conficiunt, in quantitate nucis avellane seu gallice sine potu vel cum potu boni vini. Si quis autem hunc habere non posset, tunc loco eius comedat unam vel duas aut tres nuces gallicas cum tot ficubus et modicum de foliis rute recentis aut contundat simul nuces predictas, ficus, lauribaccas et rutam et cum melle despumato miscendo loco confectus amari demane comedat in quantitate nucis gallice. Si hiis caret, recipiat unam tostam panis de aceto aut cepas aut allium de aceto aut tostam panis cum bono vino. Si vero est ita pauper, quod nullum predictorum habere potest, tunc sumat morsellum panis tosti cum caseo, si habet, et sic cito ab aere infecto vel homine non inficietur.

Item odoret spongiam aceto intictam aut perfusam aut absinthium, et si dives fuerit, faciat sibi pomum de ambra/f. 95r/ et aliis rebus odoriferis in apoteca.

Item in loco habitacionis sue faciat fumigia. Si dives fuerit, cum ligno aloes, mirra, thure et aliis bene odoriferis rebus, si est pauper, tunc cum granis iuniperi vel absinthio et aliis rebus odoriferis inponendo super mundas ac minutas prunas, et odorem illarum ad nares suscipiat.

Item optimum est bis vel ter in septimana in introitu lecti tres vel quinque pillulas pestilenciales cum cervisia aut quocunque alio potu, quia ${ }^{132}$ scribunt doctores medicine, quod qui hiis pillulis usi sunt, nunquam vel raro a pestilencia sunt infecti aut infirmati.

Item valet saltem semel infra mensem vel amplius purgare corpus cum aliquali leni medicina, scilicet cassiafistula vel dyaprunis aut alia medicina competenti secundum informacionem alicuius periti in medicina.

Item consuetis valet sangwinis minucio tempore ad hoc apto.

Item quilibet timens pestem fugiat balnea, presertim conmunia nec cum multis hominibus balnetur.

Item fugiat fructus crudos, boletos et pisces de lacu et sine squamis.

Item fugiat medonem quia opilat.

Utatur ferculis cum aceto aut cepis et caveat a carnibus porcinis et huiusmodi.

Hiis premissis, si aliquem apostema invaserit, sic procedat in cura:

Primo quam cito apostema oritur, statim priusquam XX hore transient, fiat de vena sangwinis minucio tali modo: $\mathrm{Si}$ apostema fuerit circa aures, tunc fiat minucio de cephalica eiusdem partis, scilicet dextre, si fuerit circa dextram aurem, et si paciens fortis est, fiat eciam minucio de altera parte, scilicet sinistra, de cephalica.

132 quia emendavi : qui ms. 
/95v/ Si autem fuerit apostema sub ascellis, hoc est sub humeris, tunc fiat flebotomia de vena manus, que est inter parwum digitum et sequentem et hoc de eodem brachio, sub quo est apostema. Deinde de altera manu, minus si tollerare potest infirmus.

$\mathrm{Si}$ vero oriatur apostema in iguinibus, hoc est circa pudibunda, tunc fiat flebotomia de eodem pede de vena virginea, que est circa talum, et de altero pede modicum, ut supra scriptum est.

Item supradicte minuciones sangwinis fiant, si apostema alicui fuerit in die.

Si autem in nocte et fuerit ante medium noctis, tunc si habere potest minucionem, minuat sangwinem modo supradicto et in diescente sumat tyriacam in quantitate nucis parwe cum vino sinplici vel melius cum vino, in quo sunt cocta salvia, absinthium, menta, et tunc deponendo se non surgat, nisi prius sudet. Si autem sudare non potest, tunc apponat lateres calidas vel flaskam aque calide plenam ad plantam pedum aut supra pectus et sudabit.

Si autem apostema ortum fuerit circa ortum solis, tunc prius in die minuat et post horam vesperarum non repletus cibo vel post medium noctis tyriacam sumat modo supradicto. Item post hoc post aliquot horas ponatur ventosa sub apostemate, et si fuerit locus aptus, scarificetur. Si vero non fuerit locus aptus, dimittatur. Locus ergo aptus erit in pedibus et manibus, sed non in collo vel circa aures etc.

\section{Explicit remedium.}

Nota electuarium in pestilencia secundum magistrum Gallum: Rec. Nuces gallicas XX, ficuum mundorum XV, rute manipulum I, radices genciane dragmas II et semis, aristologie dragmam I, salis conmunis distillati ad quantitatem nucis magne, tormentille manipulum I, mellis ad quantitatem omnium. Conficiatur electuarium, de quo utatur ieiuno stomacho ad quantitatem nucis magne, et deponat se, ut sudet etc. 


\section{Příloha 3 - Contra pestilenciam consilium}

Contra pestilenciam consilium magistri Cristanni

Primo fugere loca pestilentica et similiter personas pestilenticas.

Item uti pillulis pestilencialibus semel aut bis in ebdomada V vel VII sumendo in introitu lecti.

Item ieiunus non transeas ad pestilenticos, sed omni mane sumas tostam panis ex aceto vel nucem avelanam cum rutha vel aliquot grana iuniperii vel si placet avicula assa cum aceto vel bono vino. Et loco illo ${ }^{133}$ valet panis cum caseo pro pauperibus et tyriaca rusticorum, idest aleum.

Eciam esse letum et deponere timorem pestis.

Si autem venerit apostema, tunc suadent docti uti tyriaca ad quantitatem unius nucis in vino.

Et fiat apercio vene et hec ultra sex horas non negligatur.

Si apostema apparuerit sub ascella, hoc est sub brachio, tunc minucio fiat de salvatella eiusdem brachii, que est inter fidium et auricularem.

$\mathrm{Si}$ autem in inguinis, ${ }^{134}$ hoc est sub pudibundis locis, fiat de virginea vena ${ }^{135}$ eiusdem partis pedis.

Si autem sub aure, tunc de cephalica eiusdem partis, que est inter pollicem et indicem.

Inungatur eciam apostema tyriaca, ne venenosa materia cor cicius cupiat petere.

Explicit.

133 Illo : horum Strah.

134 Inguinis : in gingivis corr. al. manu in inguibus Strah.

135 vena emendavi : venea $m s$. 


\title{
DANA STEHLÍKOVÁ
}

\section{Magister Christian von Prachatitz zugeschriebene Pestschriften}

\section{ZUSAMMENFASSUNG}

Unter dem Namen Christian von Prachatitz ( $\dagger$ 1439) haben sich mehrere verschiedene Pestabhandlungen in Latein, Tschechisch und Deutsch erhalten, die bisher noch nicht eingehend untersucht worden sind. Der Artikel beschäftigt sich mit einem Vergleich sämtlicher bisher bekannter Schriften, revidiert auf prinzipielle Weise das von Pavel Spunar erstellte Verzeichnis der erhaltenen Handschriften (Repertorium auctorum Bohemorum provectum idearum post universitatem Pragensem conditam illustrans, I, Wrocław usw. 1985, S. 117-122) und bringt neue Befunde hinsichtlich der Verfasserschaft einzelner Texte und ihrer wechselseitigen Beziehungen.

Von den drei lateinischen Pestschriften, die in den Handschriften unter Christians Namen laufen, kann offenbar nur das Regimen in pestilencia (Bratislava, Slovenská akadémia vied, 392, f. 94v-95v), das um 1430 verfasst wurde, als seine Schrift erachtet werden. Dieser Text ist auch in einer alttschechischen Fassung erhalten, und zwar in drei Abschriften, von denen weder ihre lateinische Vorlage noch der Name des Autors bislang bekannt waren. Irrtümlich für Christians Werk gehalten wurde hingegen die sog. Zpráva proti šelmovému času, welche eine Übersetzung einer anderen, Remedium reportatum magistri Cristanni (Prag, Národní knihovna ČR, IX A 4, f. $\left.168 \mathrm{v}^{\mathrm{a}}-169 \mathrm{r}^{\mathrm{a}}\right)$ genannten lateinischen Pestschrift sein soll.

Neu ermittelt werden konnte, dass 1. die Zpráva keine Übersetzung des lateinischen Remedium ist und dass 2. das Remedium kein Werk des Christian ist, sondern dass es sich hierbei um ein wirkliches reportatum, das heißt um einen Text handelt, den sich Christian entsprechend dem Vortrag seines Lehrers aufzeichnete. Seine einzige erhaltene Aufzeichnung des Remedium ist nicht in das Jahr 1409 zu datieren, wie dies die ältere Literatur tat, sondern bereits in das Jahr 1390, als Christian begann, offenbar Medizin zu studieren. Eine alttschechische Übersetzung des Remedium ist bisher zwar nicht entdeckt worden, doch kennen wir zehn Abschriften seiner deutschen Fassung, die als Theriak-Pest-Traktat bezeichnet wird. Keine dieser Abschriften ist im Repertorium verzeichnet. In der Beilage sind drei lateinische Kurztraktate gegen die Pest abgedruckt, die mit Christians Namen verbunden werden (Regimen in pestilencia und Contra pestilenciam consilium werden hier erstmals herausgegeben, das Remedium reportatum wird hier erneut nach der Handschrift mit mehreren Berichtigungen der älteren Sudhoffschen Ausgabe von 1913 publiziert).

Deutsche Übersetzung Wolf B. Oerter

\author{
Dana Stehliková \\ Ústav klasických studií, Filozofická fakulta, Masarykova univerzita, Brno \\ Dana.Stehlikova@phil.muni.cz
}

